Article

\title{
The Determination of Concession Period for Build-Operate-Transfer Solar Photovoltaic Power Project under Policy Incentives: A Case Study of China
}

\author{
Yu Zeng and Weidong Chen * \\ College of Management and Economics, Tianjin University, Tianjin 300072, China \\ * Correspondence: chenweidong@tju.edu.cn
}

Received: 4 July 2019; Accepted: 9 September 2019; Published: 12 September 2019

check for updates

\begin{abstract}
Since the concession period is one of the most crucial variables influencing the success of a photovoltaic (PV) power project under build-operate-transfer (BOT) mode, this paper presents a real option game model-which integrates the real option and cooperative game theory-to determine the optimal concession period of the BOT solar PV power project under policy incentives by considering the value of the option to defer. In the proposed model, an effective interval of concession period for the BOT project was identified by using a real option, and the equilibrium value of the concession period was obtained by applying classical optimization theory. To evaluate our model, we empirically determined the optimal concession period for the BOT solar PV power project in China, and a sensitivity analysis was conducted to demonstrate how relevant influential factors, which are presented in the model, affect the equilibrium value of the concession period and its effective interval. The results indicate that the current investment environment in China could successfully implement the BOT solar PV power project under policy incentives, including initial cost subsidy and the feed-in tariffs mechanism. While the high volatility of electricity demand, investment cost, and land-use rent fee can lead the failure of the BOT solar PV project implementation, promoting the technological development of PV power generation, maintaining the market stability, and increasing the policy incentives can help the BOT power project to be arranged with an optimal concession period. In addition, the feed-in tariffs mechanism is more helpful than the initial cost subsidy for winning the BOT contract.
\end{abstract}

Keywords: photovoltaic power generation; build operate transfer; concession period; China

\section{Introduction}

Nowadays, due to the problems of environmental pollution and energy shortage, renewable energy generation has played a strategic role in promoting the utilization of renewable energy worldwide, especially for the countries with a heavy reliance on fossil fuels [1,2]. Among multiple renewable energy sources, solar energy is a theoretically inexhaustible and emissions-free energy source, and generation from solar energy sources is a clean and renewable operation mode of electrical system, which could perfectly match the industry electricity load in time and also eliminate the electric energy loss during the long-distance transmission process since the PV project is close to the location of load [3]. Thus, solar photovoltaic power has become one of the most promising sources of renewable energy in the future world [4].

Nevertheless, since the investment cost of solar PV power generation is still high, the development of solar PV power generation has been severely constrained by the limitation of government budgets and the investor's affordability in China [5]. In order to broaden the funding source for the solar PV 
power generation project and accelerate the electricity market-oriented reform in China, some financing modes, such as BOT, securitization, and peer-to peer financing, have been encouraged by the government [6]. Within these modes, the BOT mode has the advantages of massive capital, efficient operation, and advanced technologies compared with other modes. Hence, it has been taken as an important policy measure to promote the investment in the PV power project $[7,8]$. Under this favorable environment, the BOT mode has been used in a number of solar PV power projects, such as Shandong, Hunan, Gansu PV power, and has obtained certain achievements, which alleviates the financial burden of the government and stimulates private participation in the PV power project.

So far, although many advantages have been expected to be achieved from the BOT mode application towards the solar PV power project, which include bringing in needed capital, improving the project operation efficiency, and promoting the technical progress, there exist multiple factors that influence the success of a BOT power project. For example, project feasibility, which includes the acceptability of end users [9,10], expected profitability of project [11,12], and the level of complexity for technologies that are adopted in the project [8]; policy environment, which includes the legislations of project [13], stability of political environment [14], and government incentives [15]; and also the project developers' business capacity, including both the government and private investors [16]. Hence, appropriate arrangements of BOT contracts play a strategic role in the development of solar PV power projects under BOT mode. Note that for the arrangement of BOT contract, the concession period is the key decision variable since its length directly influences the benefits and welfare of both the government and the private sector [17]. In this study, we give emphasis on the concession period determination for the BOT solar PV power project.

The investment decision on the solar PV power project has three key characteristics. Firstly, its investment is partially or completely irreversible. Secondly, multiple uncertain factors exist for PV power project investment, e.g., relevant policies, market environment, and technology development. Thirdly, the project investment timing is discretionary. With regard to this characteristic, the concession period determination should take the value of the option to defer into consideration [18]. Nevertheless, among the broader literature on the determination of the concession period in the BOT project (e.g., $[19,20])$, many studies use the net present value (NPV) method. For example, $\mathrm{Xu}$ and Moon [21] proposed a stochastic revenue and cost model for determining a BOT concession period. However, the NPV method fails to consider the influences of uncertain factors. Instead, other authors developed optimization methods, such as the real option model [22], Monte Carlo simulation [23], or the real option model combined with Monte Carlo simulation [24,25], for determining the concession period, in which various factors and their uncertainties that impact the BOT project implementation are considered. However, the methods proposed ignore the interactions between the government and the private sector for concession period determination. Then, some scholars have proposed the game-theoretical model $[26,27]$ and the game-theoretical model combined with real option $[28,29]$ to reflect the dynamic interaction relationship between the two major stakeholders, i.e., the private sector and the government, with respect to concession negotiation for concession period determination. Nevertheless, as the relationship between the private sector and the government is not always incorporative, the success of a BOT project relies on the cooperation of the two major stakeholders. Besides, a regulator will encourage the BOT project if it improves the economic efficiency, which often is measured by the sum of surpluses for the major stakeholders [30]. Considering these, our study proposes a real option game model, which integrates the real option and cooperative game theory, to determine the optimal concession period of the BOT solar PV power project under policy incentives, which considers the value of the option and is built based on the investment environment of China. In the proposed model, an effective interval for the concession period is identified by using real option, and the equilibrium value of the concession period is obtained by applying classical optimization theory. The effects of relevant influential factors were also evaluated by investigating the dynamics of the effective interval for a concession period and its equilibrium value under the change of these influential factors through sensitivity analysis. Accordingly, the questions we aimed to answer are as follows: Can a solar 
power project successfully win a BOT contract under the current investment environment in China, considering the determination of concession period? How do relevant influential factors affect the concession period, which includes unit generating capacity, the volatility of electricity demand, policy incentives (i.e., initial cost subsidy and the feed-in tariffs mechanism), electricity price, unit investment cost, and land-use rent fee of the BOT project?

The rest of the paper proceeds as follows: In Section 2, we define the BOT mode, and a review of earlier relevant studies is provided. Section 3 formulates a methodology for determining the optimal concession period of the BOT solar photovoltaic project under policy incentives. Section 4 presents an empirical analysis of China, and finally, some conclusions and policy implications are given in Section 5 .

\section{The Concept Definition and Literature Review}

Build-operate-transfer originates from 1660 when the construction and engineering of turnpike roads were commissioned by the U.K. government and the private investors were conferred the permission to develop and operate the projects [31]. Although the BOT mode has been applied for decades, no clear consensus remains regarding its concept. As a frequent form of public-private partnership mode, the BOT mode can be defined as follows: Through the cooperation between the government and the private sector, a concession contracture arrangement is formed to permit the private sector to recoup its investment during the concession period and also to meet the capital requirement of the government to provide public goods and services, thereby achieving a win-win situation $[14,32]$. Figure 1 shows the general process of a BOT project. For developing a BOT project, three main stages exist, which include the pre-development stage, concession period stage, and transfer to government stage. In the pre-development stage, the preliminary qualification of the BOT project is firstly evaluated, which includes identifying the project, defining financing form, and studying the feasibility, etc. Then, the government makes the decision, and the project is put out to tender. This phase will last until the concession contract is awarded. In the concession period stage, the project is successfully arranged for a private sector, and the sector will be responsible for building and then operating it to achieve benefits. At the end of the concession period, the project will be transferred from the private sector to the government to be operated until the end of the project lifetime. According to these, the stages can further be divided into six basic phases comprising the preliminary qualification evaluation phase, tendering phase, concession award phase, construction phase, operation phase, and transfer phase. Among these phases, only the construction phase and the operation phase are included in the concession period [33].

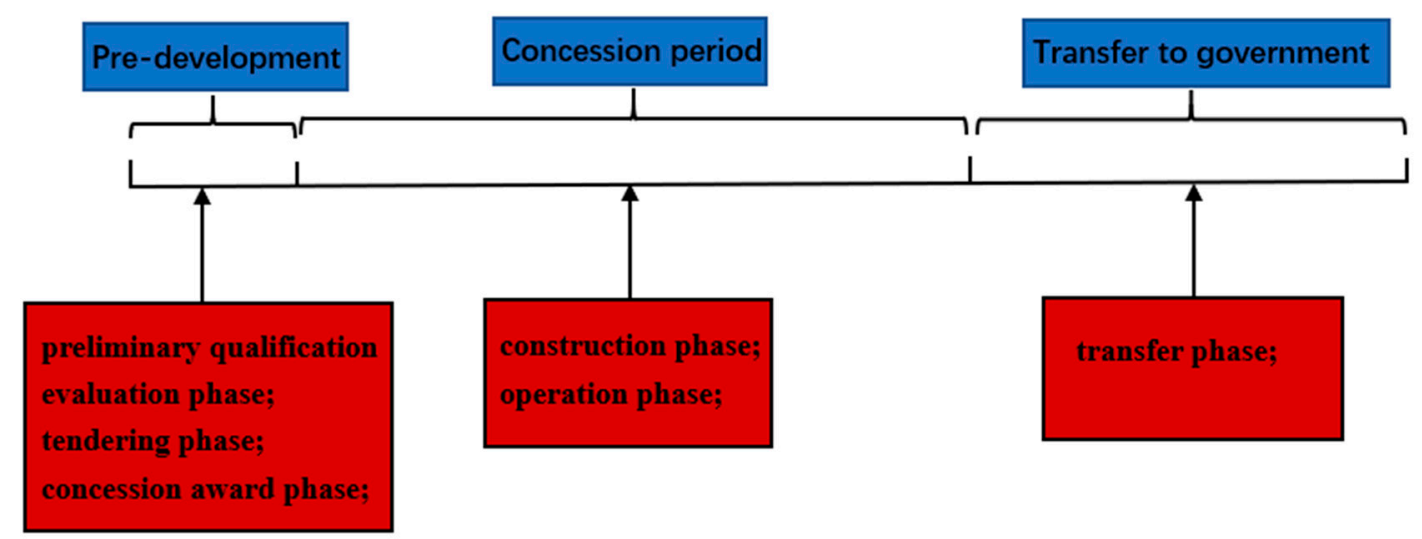

Figure 1. The phases for developing a build-operate-transfer (BOT) project.

Previously, BOT power projects have drawn attention from both academics and industry practitioners, which is well-evidenced in the literature. For example, Bakatjan et al. [34] presented the capital structure model, which combines a financial model and linear programming for determining the 
optimal equity level of decision-makers in the evaluation stage of a BOT hydroelectric power project in Turkey. Deng et al. [35] proposed a methodology for assisting the Energy Service Company to maintain competitiveness for winning BOT bids, taking the relevant uncertainties into consideration. Xu et al. [36] conducted an extensive literature survey and then used a case study to identify the key risks factors that impact on BOT waste-to-energy projects. Zhao et al. [15] adopted a multi-facet qualitative approach to investigate the factors influencing the success of BOT electric power projects in China. Some studies have addressed the issue of concession period determination for BOT power projects. For example, Deng et al. [37] developed a simulation-based decision model for contract period determination in BOT energy projects. Song et al. [38] proposed a system dynamic model combined with prospect theory to determine the concession period and subsidy for BOT waste-to-energy incineration projects. However, studies that specifically focus on the concession period determination for BOT renewable energy projects are limited. The focus of our paper is to propose a real option game model, which integrates the real option and cooperative game theory, to determine the optimal concession period of the BOT solar $\mathrm{PV}$ power project under policy incentives, which considers the value of the option and is built based on the investment environment of China. In the proposed model, an effective interval for the concession period is identified by using real option theory, and the equilibrium value of the concession period is obtained by applying classical optimization theory. Then, the effects of relevant influential factors on the BOT solar PV power project, which have not received much prior attention, are investigated so as to derive more insightful policy implications for guiding BOT solar PV power project implementation.

\section{Methodology}

In this study, real option will be used in combination with the cooperative game theory to determine the optimal concession period of the build-operate-transfer solar PV power project, assuming exchangeable utility and full public information $[39,40]$. In this cooperative framework, the objective of the concession period determination is to maximize the sum of the project values of the two major stakeholders (i.e., the government and the private sector), considering the value of the option to defer. As shown in Figure 2, the optimal concession period is determined through two procedures in which an effective interval for the concession period is identified by using real option theory first, and the equilibrium value of the concession period is then obtained by applying classical optimization theory. Finally, the effects of relevant influential factors on the determination of concession period are analyzed to derive the policy implications for guiding the BOT solar PV power project implementation.

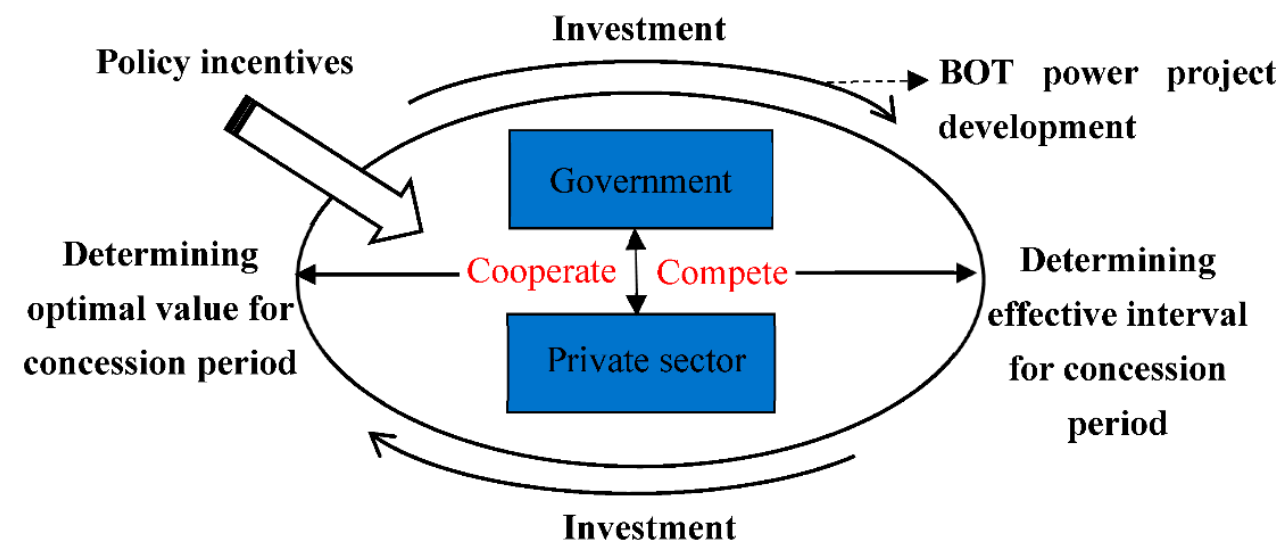

Figure 2. The methodology framework.

\subsection{Real Option Models}

\subsubsection{Basic Real Option Model for Operating the BOT Photovoltaic Power Project}

Consider that a solar PV project with lifetime $T_{f}$ is invested under BOT mode in year $t\left(1 \leq t \leq t_{v}\right.$, where $t_{v}$ is the last stage for the validity period of the project investment). Suppose that the project 
construction can be completed instantaneously with initial investment $\operatorname{cost} C_{t}$ [41]. Since the electricity quantity is devoted to satisfy the electric demand, the quantity of power electricity to be sold is uncertain and can be affected by various factors, such as electricity market, relevant policies, and consumer preferences, etc. Thus, this study employs geometric Brownian motion to characterize the uncertainties for the electricity quantity, which has already been widely used in previous studies (e.g., [42-44]). Mathematically, we derive the formula as follows:

$$
d E q_{t}^{e}=\alpha E q_{t}^{e} d t+\sigma E q_{t}^{e} d z(t)
$$

where $E q_{t}^{e}$ is the quantity of power electricity, $\alpha$ denotes the drift of the electricity demand, $\sigma$ refers to the volatility rate of the electricity demand, and $d z(t)$ presents the increment of a standard Wiener process $d z(t)=\varepsilon_{t} \sqrt{d t}$, where $\varepsilon_{t}$ is a normally distributed random variable with zero mean and unit standard deviation (i.e., the expected value of $E q_{t}^{e}$ is $E\left[E q_{t}^{e}\right]=E q_{0}^{e} e^{\alpha \mathrm{t}}$ ).

The project value of this BOT photovoltaic power project is the sum of two terms, which constitutes the total yearly cash flow in its lifetime, which includes the revenues through selling electricity minus the operation and maintenance cost, and the project initial investment cost. As the project net present value depends on many uncertain factors during its implementation, it is plausible to express the project value by using its expectation $E[\cdot]$. Hence, the total net present value of the photovoltaic power project under BOT mode can be expressed by

$$
V_{t}=E\left[\int_{t}^{t+T_{f}} e^{-r(s-t)} \pi_{s} d s-C_{t}\right]
$$

where $\pi_{t}$ denotes the yearly cash flow of the power project, and $r$ refers to the discount rate of the PV power project.

The yearly cash flow $\pi_{t}$ of the PV power project generally comprises the returns through selling electricity, and the operation and maintenance cost. Mathematically, the yearly cash flow of the solar $\mathrm{PV}$ power generation project can be expressed by

$$
\pi_{t}=E p_{t}^{e} \cdot E q_{t}^{e}-u m o c_{t} \cdot E q_{t}^{e}
$$

where $E p_{t}^{e}$ is the price of electricity, and $u m o c_{t}$ denotes the operation and maintenance cost per unit electricity output.

\subsubsection{Identify the Option Models of Both the Government and the Private Sector}

During the project lifetime, both the private sector and the government can operate the PV power project, but they operate in different periods, which is divided by the concession period of the BOT project. According to the benefit-costs analysis of both the government and the private sector, we can then identify the real option models as follows:

(1) Real option model considering the private sector's strategy for the PV power investment

For the private sector, the yearly cash flow $\pi_{p, t}$ comprises the yearly cash flow of the PV power project $\pi_{t}$, and land-use rent fee $R_{t}$ during the concession period, i.e., $\pi_{p, t}=\pi_{t}-R_{t}$. Hence, the total net present value of the private sector for investing in the PV power project under BOT mode can be expressed by

$$
V_{p, t}\left(E q_{t}^{e}\right)=E\left[\int_{t}^{t+T_{c}} e^{-r(s-t)} \pi_{p, s} d s\right]-C_{p, t}
$$

where $C_{p, t}$ denotes the initial investment cost of the private sector, and $T_{c}$ denotes the concession period of the BOT solar PV power project $\left(0 \leq T_{c} \leq T_{f}\right)$.

As for the BOT project, the private sector is responsible for the project construction after the concession has been assigned, and the initial investment cost of the private sector denotes the initial 
capital cost of the PV project. Mathematically, the initial investment cost of the private sector can be expressed as

$$
C_{p, t}=U I_{t} \cdot I C
$$

where $U I_{t}$ is the initial investment cost per capacity, and IC refers to the installed capacity.

When the private sector operates the BOT solar PV power project within the concession period, the private sector would pay the government land-use rent fees, which includes the compensation fee for the land and the safety care fee (as well as other fees). This can be calculated as a portion $\varepsilon$ of the project's yearly earnings through selling electricity minus the operation and maintenance costs. Mathematically, we can derive the following formula:

$$
R_{t}=\varepsilon \cdot\left(E p_{t}^{e} \cdot E q_{t}^{e}-O M C_{t} \cdot E q_{t}^{e}\right)
$$

Then, let $F_{p}\left(E q_{t}^{e}\right)$ denote the value of the private sector before project investment and assume that the private sector is risk-neutral, and the option value to invest in the project $F_{p}\left(E q_{t}^{e}\right)$ should meet the Bellman Equation [45]. We obtain that

$$
r F_{p}\left(E q_{t}^{e}\right) d t=E\left[d F_{p}\left(E q_{t}^{e}\right)\right]
$$

Then, the option value for the private sector to invest in the BOT project $F_{p}\left(E q_{t}^{e}\right)$ should be the solution of the equilibrium differential equation [46], which can be represented by

$$
\frac{1}{2} \sigma^{2}\left(E q_{t}^{e}\right)^{2} \frac{\partial^{2} F_{p}\left(E q_{t}^{e}\right)}{\partial\left(E q_{t}^{e}\right)^{2}}+(r-\delta) E q_{t}^{e} \frac{\partial F_{p}\left(E q_{t}^{e}\right)}{\partial E q_{t}^{e}}-r F_{p}\left(E q_{t}^{e}\right)=0
$$

where $\delta=r-\alpha, \delta$ stands for the rate of return shortfall, and, to ensure the convergence of solution, we assume that $\delta>0$ (i.e., $r>\alpha$ ).

To ensure that the private sector invests at the time when the option value is maximized, the differential equation (8) must be solved subject to the boundary conditions (9) and (10), where the boundary condition (9) is the value-matching condition, which illustrates that the private sector's option is exercised as the net value at this time, and condition (10) is the smooth-pasting condition, which is to ensure that the exercise trigger is determined by achieving the maximum value of the option. Mathematically, the formulas are given as follows:

$$
\begin{aligned}
& F_{p}\left(E q_{p, t}^{e *}\right)=V_{p}\left(E q_{p, t}^{e *}\right) \\
& F_{p}^{\prime}\left(E q_{p, t}^{e *}\right)=V_{p}^{\prime}\left(E q_{p, t}^{e *}\right)
\end{aligned}
$$

where $E q_{p, t}^{e *}$ is the minimum value of electricity quantity (threshold) to trigger the private sector to invest in the BOT photovoltaic power project.

Through the procedure mentioned above, we obtain the private sector's investment threshold $E q_{p, t}^{e *}$, and the option value of private sector to invest in the PV project $F_{p}\left(E q_{t}^{e}\right)$, which are derived as follows:

$$
\begin{gathered}
E q_{p, t}^{e *}=\frac{\vartheta}{\vartheta-1} \cdot \frac{C_{p, t} \cdot \delta}{(1-\varepsilon) \cdot\left(E p_{t}^{e}-O M C_{t}\right) \cdot\left(1-e^{-\delta T_{c}}\right)} \\
F_{p}\left(E q_{t}^{e}\right)=\left\{\begin{array}{cc}
\frac{C_{p, t}\left(\frac{E q_{t}^{e}}{\vartheta-1}\left(\frac{\vartheta}{E q_{, t}^{e *}}\right)\right.}{E q_{t}^{e}<E q_{p, t}^{e *}} \\
\frac{\pi p, t \cdot\left(1-e^{-\delta T_{c}}\right)}{\delta}-C_{p, t} & E q_{t}^{e} \geq E q_{p, t}^{e *}
\end{array}\right.
\end{gathered}
$$

where $\vartheta=\frac{1}{2}-\frac{\alpha}{\sigma^{2}}+\sqrt{\left(\frac{\alpha}{\sigma^{2}}-\frac{1}{2}\right)^{2}+\frac{2 r}{\sigma^{2}}}>1$. 
According to Equation (12), if the electricity quantity $E q_{t}^{e}$ is below the threshold $E q_{p, t}^{e *}$, the option value of private sector to invest in the PV power project would be the value to wait, which means that the private sector can invest in the BOT photovoltaic power project only when the quantity of electricity $E q_{t}^{e}$ exceeds the private sector's investment threshold $E q_{p, t}^{e *}$, i.e., $E q_{t}^{e} \geq E q_{p, t}^{e *}$. Hence, substituting Equation (10) into this inequation constraint, we then derive the minimum concession period of BOT photovoltaic power project that the private sector can accept as the following:

$$
T_{p, c}^{\min }=\frac{1}{\delta} \ln \left(\frac{(\vartheta-1) \cdot \pi_{p, t}}{(\vartheta-1) \cdot \pi_{p, t}-\vartheta \cdot C_{p, t} \cdot \delta}\right)
$$

Assume the demand of electricity is sufficient to trigger the investment of the private sector. The value function of the private sector to invest in the BOT project can be expressed by

$$
V_{p, t}\left(E q_{t}^{e}\right)=\frac{\pi_{p, t} \cdot\left(1-e^{-\delta T_{c}}\right)}{\delta}-C_{p, t}
$$

(2) Real option mode considering the government's strategy for the PV power investment

For the government, the yearly cash flow during the concession period $\pi_{g, s}$ comprises the social benefits of PV power generation $S R_{S}$ and the land-use rent fee from the private sector $R_{S}$, i.e., $\pi_{g, s}=S R_{s}+R_{s}$. After the concession period, the yearly cash flow of the government $\pi_{g, t}^{\prime}$ comprises the yearly cash flow of the power project $\pi_{t}$, and social benefits of PV power generation $S R_{t}$, i.e., $\pi_{g, t}^{\prime}=\pi_{t}+S R_{t}$. Thus, the total net present value of the government $V_{g}\left(E q_{t}^{e}\right)$ in BOT solar PV power project can be formulated as follows:

$$
V_{g, t}\left(E q_{t}^{e}\right)=E\left[\int_{t}^{t+T_{c}} e^{-r(s-t)} \pi_{g, s} d s+\int_{t+T_{c}}^{t+T_{f}} e^{-r(s-t)} \pi_{g, t}^{\prime} d s\right]-C_{g, t}
$$

where $C_{g, t}$ denotes the initial investment cost of the government, and the initial investment cost of the BOT project $C_{t}=C_{p, t}+C_{g, t}$.

For the PV power project under BOT mode, the government is responsible for the upfront investment costs of the PV power project, which include the expenditures for project planning and design, and its feasibility analysis (as well as other costs). Since the upfront costs of the project can be expressed by a portion of the capital cost of the power project, the initial investment cost of the government can be formulated as follows:

$$
C_{g, t}=\gamma \cdot U I_{t} \cdot I C
$$

where $\gamma$ denotes the proportion between the upfront costs and the initial capital costs of the BOT photovoltaic power project.

The social benefit of the BOT photovoltaic power project is the sum of two terms, which include the environmental benefits and the energy conservation benefits for PV power generation. Suppose that $\beta$ and $\omega$ are respectively the degree of society's benefits with unit non-renewable energy saved and the degree of the society's environmental benefits with unit $\mathrm{CO}_{2}$ emission reduced, $Q_{e}$ and $Q_{c}$ represent, respectively, the quantities of energy consumption and $\mathrm{CO}_{2}$ emission reduced for generating unit non-renewable energy electricity. The social benefit of the BOT solar PV power project can be formulated by

$$
S R_{s}=\beta \cdot Q_{e} \cdot E q_{t}^{e}+\omega \cdot Q_{c} \cdot E q_{t}^{e}
$$

As for China, the conventional coal-fired power plant still remains predominant for energy consumption and $\mathrm{CO}_{2}$ emission production. In order to quantify the social benefits, we introduce coal-fired power generation as the weighted objective to quantify both the energy conservation benefits and the society's environmental benefits. 
As the private sector, we also assume the government is risk-neutral and let $F_{g}\left(E q_{t}^{e}\right)$ denote the value of the government before project investment. The option value to invest in the project $F_{g}\left(E q_{t}^{e}\right)$ should meet the Bellman Equation [45]. We obtain that

$$
r F_{g}\left(E q_{t}^{e}\right) d t=E\left[d F_{g}\left(E q_{t}^{e}\right)\right]
$$

Then, $F_{g}\left(E q_{t}^{e}\right)$ must be the solution of the following equilibrium differential equation [46], which can be represented by

$$
\frac{1}{2} \sigma^{2}\left(E q_{t}^{e}\right)^{2} \frac{\partial^{2} F_{g}\left(E q_{t}^{e}\right)}{\partial\left(E q_{t}^{e}\right)^{2}}+(r-\delta) E q_{t}^{e} \frac{\partial F_{g}\left(E q_{t}^{e}\right)}{\partial E q_{t}^{e}}-r F_{g}\left(E q_{t}^{e}\right)=0
$$

The equilibrium differential equation (19) is solved subject to the boundary conditions (20) and (21) to ensure that the government invests at the time when the option value is maximized. Hereon, the value-matching condition (20) states that the government's option is exercised as the net value at this moment, and the smooth-pasting condition (21) ensures that the exercise trigger must be determined to maximize the option value. Mathematically, the formulas are described as follows:

$$
\begin{aligned}
& F_{g}\left(E q_{g, t}^{e *}\right)=V_{g}\left(E q_{g, t}^{e *}\right) \\
& F_{g}^{\prime}\left(E q_{g, t}^{e^{*}}\right)=V_{g}^{\prime}\left(E q_{g, t}^{e *}\right)
\end{aligned}
$$

where $E q_{g, t}^{e *}$ is the minimum value of electricity quantity (threshold) to trigger the government to invest in the BOT solar PV power project.

We then obtain the threshold of the government $E q_{g, t}^{e *}$ and the option value of the government to invest in the PV power project under BOT mode $F_{g}\left(E q_{t}^{e}\right)$. The formulas are derived follows:

$$
\begin{aligned}
& E q_{g, t}^{e *}=\frac{\vartheta}{\vartheta-1} \cdot \frac{C_{g, t} \cdot \delta}{(1-\varepsilon) \cdot\left(E p_{t}^{e}-O M C_{t}\right) \cdot e^{-\delta T_{c}}-\left(E p_{t}^{e}-O M C_{t}+\beta \cdot Q_{e}+\omega \cdot Q_{c}\right) \cdot e^{-\delta T_{f}}+\beta \cdot Q_{e}+\omega \cdot Q_{c}+\varepsilon \cdot\left(E p_{t}^{e}-O M C_{t}\right)} \\
& F_{g}\left(E q_{t}^{e}\right)=\left\{\begin{array}{c}
\frac{C_{g, t}}{\vartheta-1}\left(\frac{E q_{t}^{e}}{E q_{g, t}^{e *}}\right)^{\vartheta} E q_{t}^{e}<E q_{g, t}^{e *} \\
\frac{\left(\pi_{g, t}^{\prime}-\pi_{g, t}\right) \cdot e^{-\delta T_{c}}-\pi_{g, t}^{\prime} \cdot e^{-\delta T_{f}}+\pi_{g, t}}{\delta}-C_{g, t} \quad E q_{t}^{e} \geq E q_{g, t}^{e *}
\end{array}\right.
\end{aligned}
$$

When the electricity quantity $E q_{t}^{e}$ is below the threshold $E q_{g, t}^{e *}$, the option value of the government to invest in the BOT project would be the value to wait. Thus, the government can only invest in the PV project at the time when the electricity quantity $E q_{t}^{e}$ exceeds the government's investment threshold $E q_{g, t}^{e^{*}}$, as seen in Equation (23). Substituting Equation (22) into the inequation constraint $E q_{t}^{e} \geq E q_{p, t}^{e *}$ we then derive the maximum concession period of the BOT solar PV power project that the government can permit is expressed as follows:

$$
T_{g, c}^{\max }=\frac{1}{\delta} \ln \left(\frac{(\vartheta-1) \cdot\left(\pi_{g, t}^{\prime}-\pi_{g, t}\right)}{(\vartheta-1) \cdot \pi_{g, t}^{\prime} \cdot e^{-\delta T_{f}}+\vartheta \cdot C_{g, t} \cdot \delta-(\vartheta-1) \cdot \pi_{g, t}}\right)
$$

Assume that the electricity demand is sufficient to trigger the investment of the government. The value function of the government can be expressed by

$$
V_{g, t}\left(E q_{t}^{e}\right)=\frac{\left(\pi_{g, t}^{\prime}-\pi_{g, t}\right) \cdot e^{-\delta T_{c}}-\pi_{g, t}^{\prime} \cdot e^{-\delta T_{f}}+\pi_{g, t}}{\delta}-C_{g, t}
$$

It is should be noted that, for the determination of the project's concession period $T_{\mathcal{C}}$, the minimum concession period of the PV power project under BOT mode that the private sector can accept $T_{p, c}^{m i n}$ 
must be lower than the maximum value of the concession period that the government can permit $T_{g, c}^{\max }$ to ensure both the private sector and the government take the strategy of investing in the BOT photovoltaic power project. We obtain that

$$
T_{p, c}^{\min } \leq T_{g, c}^{\max }
$$

According the analysis above, we identify the effective interval for the concession period, which can be expressed by

$$
T_{p, c}^{\min } \leq T_{c} \leq T_{g, c}^{\max }
$$

Besides, when the minimum value of the concession period for the BOT project that the private sector can accept $T_{p, c}^{m i n}$ is lower than the maximum value of the concession period that the government can permit $T_{g, c}^{\max }$, an extra constraint condition will exist for the electricity quantity to trigger the BOT project investment. Substituting Equations (13) and (24) into Equation (26), we then obtain that

$$
E q_{t}^{e} \geq E q_{e x, t}^{e *}=\frac{\vartheta}{\vartheta-1} \cdot \frac{\left(C_{p, t}+C_{g, t}\right) \cdot \delta}{\left(p_{t}^{e}-O M C_{t}-\varepsilon \cdot E p_{t}^{e}+\beta \cdot Q_{e}+\omega \cdot Q_{c}\right) \cdot\left(1-e^{-\delta T_{f}}\right)}
$$

where $E q_{e x, t}^{e *}$ denotes the minimum value of the electricity quantity to ensure the minimum value of the concession period that the private sector can accept is lower than the maximum value of the concession period that the government can permit for the BOT photovoltaic power project.

\subsection{Modelling the Supporting Policies for BOT Photovoltaic Power Project}

Currently, for the BOT solar PV power project, the international supporting policies still remain the financial incentives for the photovoltaic power project, which generally comprises the initial cost subsidy and the feed-in tariffs (FIT) mechanism [47]. Thus, we identify the corresponding formulas as follows.

\subsubsection{Initial Cost Subsidy}

The initial cost subsidy corresponds to the initial capital cost of the PV power project, which illustrates that the PV power project under BOT mode can be subsidized with a fixed payoff $C b_{t}$ for the unit capacity installed. As a result, the initial investment cost of the private sector in the BOT photovoltaic power project $C_{p, t}^{\prime}$ can be expressed by

$$
C_{p, t}^{\prime}=\left(U I_{t}-C b_{t}\right) \cdot I C
$$

where $C_{p, t}^{\prime}$ refers to the initial capital cost for the BOT photovoltaic power project with initial cost subsidy.

Since the initial cost subsidy for the power project comes from the government, the investment cost of the government is composed of the initial investment cost of the government before $C_{g, t}$ and the expenditure for the initial cost subsidy, which is $C b_{t}$ per unit. Mathematically, we can derive the formula as follows:

$$
C_{g, t}^{\prime}=C_{g, t}+C b_{t} \cdot I C
$$

where $C_{g, t}^{\prime}$ is the initial investment cost of the government for the BOT solar PV power project after providing the initial cost subsidy.

\subsubsection{The FIT Mechanism}

With regard to the FIT mechanism, it is a fixed payout for unit electricity produced by the PV power project. More precisely, the price of the electricity from the BOT solar PV power project comprises the 
market price of electricity and the price subsidy [48]. Mathematically, we can derive the formula as follows:

$$
E p_{t}^{e}=E p_{t}^{d}+P b_{t}
$$

where $E p_{t}^{d}$ denotes the market price of electricity, and $P b_{t}$ refers to the price subsidy for the electricity per unit.

With FIT, the government adds the expenditure for the price subsidy for electricity. Assume that once the investment is triggered, the subsidy level of electricity price is fixed and becomes a constant during the entire lifetime of the PV power project under BOT mode. Then, the net present value of the government with the FIT mechanism can be represented by

$$
V_{g, t}^{\prime}\left(E q_{t}^{e}\right)=V_{g, t}\left(E q_{t}^{e}\right)-E\left[\int_{t}^{t+T_{f}} e^{-r(s-t)} P b R_{s} d s\right]
$$

where $P b R_{t}$ is the yearly price subsidy expenditure of the government for the PV power project, and $P b R_{t}=P b_{t} \cdot E q_{t}^{e}$.

Under the influences of the policy incentives for the BOT solar photovoltaic power project, the option value of both the private investor and the government could be changed and then, to some extent, impact the concession period determination, which is closely related with the success of a BOT project. Adequate incentives for the PV power generation project under BOT mode, which include both initial cost subsidy and FIT, could help the PV power project to win a BOT contract.

\subsection{Establish the Option-Cooperative Game Model for the Optimal Concession Period of the BOT Solar Photovoltaic Power Project}

In this segment, a mathematic model which combines the real options and cooperative game is presented to determine the optimal concession period of the BOT solar PV power project. Since the implementation of the BOT photovoltaic power project is a problem of multi-agent cooperation, including the government and the private sector, an effective and stable cooperation relationship between the two agents should be developed to promote the wide deployment of the BOT solar PV power generation project $[49,50]$. Hence, apart from the trigger lines of the concession period for each major stakeholder, the concession period is determined to maximize the sum of the project's values of the two major stakeholders, which considers the value of the option to defer, i.e., option values of the stakeholders minus their option value to defer. The optimization problem of the concession period can be formulated as follows:

$$
\varphi\left(T_{c}, E q_{t}^{e}\right)=\max \left(\phi_{p, t}\left(E q_{t}^{e}\right)+\phi_{g, t}\left(E q_{t}^{e}\right)\right)
$$

where $\phi_{p, t}\left(E q_{t}^{e}\right)$ is the combined project values of the two major stakeholders, which considers the value of the option to defer, $\phi_{p, t}\left(E q_{t}^{e}\right)$ denotes the project value of the private sector considering the option value to defer, and $\phi_{g, t}\left(E q_{t}^{e}\right)$ denotes the project value of the government, which takes the option value of the government to defer into account.

The project values of the two major stakeholders considering the value of the option to defer can be obtained through the value of each stakeholder minus its option value to defer, which are respectively described as follows:

$$
\begin{aligned}
& \phi_{p, t}\left(E q_{t}^{e}\right)=V_{p, t}\left(E q_{t}^{e}\right)-\frac{C_{p, t}}{\vartheta-1}\left(\frac{E q_{t}^{e}}{E q_{p, t}^{e *}}\right)^{\vartheta} \\
& \phi_{g, t}\left(E q_{t}^{e}\right)=V_{g, t}\left(E q_{t}^{e}\right)-\frac{C_{g, t}}{\vartheta-1}\left(\frac{E q_{t}^{e}}{E q_{g, t}^{e *}}\right)^{\vartheta}
\end{aligned}
$$


Since the trigger lines for both the concession period and the electricity demand for the BOT solar $\mathrm{PV}$ project exist, let $T_{c}$ denote the strategy set of the concession period for the BOT photovoltaic power project, representing all the possible concession periods. According to the analysis in Section 3.1.2., the strategy sets can be expressed as follows:

$$
T_{c}=\left\{T_{c} \mid T_{c} \in R^{N}, T_{p, c}^{\min } \leq T_{c} \leq T_{g, c}^{\max }\right\}
$$

In order to find the optimal concession period $T_{\mathcal{c}}^{*} \in T_{\mathcal{c}}$, an equilibrium value is obtained if the following condition is satisfied [51]:

$$
\forall T_{c} \in T_{c}, T_{c} \neq T_{c}^{*}: \varphi\left(T_{c}^{*}, E q_{t}^{e}\right) \geq \varphi\left(T_{c}, E q_{t}^{e}\right)
$$

We then consider the sum of the project values of the two major stakeholders, which considers the value of the option to defer, under different concession periods granted by the government. On the basis of the classical optimization rules, we derive the first-order of $\varphi\left(T_{c}, E q_{t}^{e}\right)$ with respect to $T_{c}$ as follows:

$$
\frac{\partial \varphi}{\partial T_{c}}=\left[\left(\pi_{g, t}^{\prime}-\pi_{g, t}\right) \cdot\left(\frac{E q_{t}^{e}}{E q_{g, t}^{e *}}\right)^{\vartheta-1}-\pi_{p, t} \cdot\left(\frac{E q_{t}^{e}}{E q_{p, t}^{e *}}\right)^{\vartheta-1}\right] \cdot e^{-\delta T_{c}}
$$

Setting Equation (38) equal to zero, the equilibrium value of the concession period can be derived:

$$
T_{c}^{*}=\frac{1}{\delta} \ln \left(\frac{C_{p, t} \cdot\left(\pi_{g, t}^{\prime}-\pi_{g, t}\right)+C_{g, t} \cdot \pi_{p, t}}{C_{g, t} \cdot \pi_{p, t}+C_{p, t} \cdot \pi_{g, t}^{\prime} \cdot e^{-\delta T_{f}}-C_{p, t} \cdot \pi_{g, t}}\right)
$$

According to Equation (39), the equilibrium concession period of the PV power generation project under BOT mode is determined by the corresponding parameters in Equations (14) and (25). The equilibrium value of the concession period would change under different sets of policy incentives for the BOT solar PV power project as aforementioned, according to the analysis in Section 3.2.

\section{Empirical Study}

In this section, we apply the model formulated in Section 3 to explore the optimal concession period and incentive policies for the BOT photovoltaic power project in China, where the development of solar photovoltaic power generation plays a strategic role for the adjustment of energy structure and the reduction of carbon emissions. Currently, the electricity consumption in China has reached 6844.9 billion kilowatt hours, and within the electricity consumption, the solar PV power only accounts for $2.59 \%$, which has been 177.5 billion kilowatt hours [52]. Undeniably, there still exists great potential for the development of solar photovoltaic power projects in China. As of 2018, the total PV installed capacity has reached 174 million $\mathrm{kW}$, and the newly installed capacity has been 4.43 million $\mathrm{kW}$ [53].

\subsection{Data and Assumptions}

In this empirical analysis, we assume that the BOT photovoltaic power project, which is developed by the private investor in cooperation with the government, is sized to meet the electricity demand of local residents, equaling to $10 \mathrm{MW}$. The date needed in this empirical analysis is presented in Table 1. Unit cost per capacity of PV generation, unit generating capacity, the market price of electricity, the proportion between upfront costs and initial capital costs of PV generation, the discount rate for PV generation project, and the land-use rent fee in BOT photovoltaic power project were collected from China Photovoltaic Industry Association (Access at: http://www.chinapv.org.cn/) and enterprise survey. Unit production and operation cost was taken from [54]. The lifetime of solar PV project is 25 years. In additional, the amount of carbon emission by unit coal-fired power and unit carbon emission price were both taken from Ref. [55]. The amount of coal consumption by unit coal-fired 
power was taken from Ref. [56]. Finally, the coal price was collected from China Coal Transportation and Distribution Association (Access at: https://www.cctd.com.cn/).

Before running the model, some parameters of stochastic variables need to be set. As we employed geometric Brownian motion to govern the electric demand in this study, both the drift and volatility terms were estimated by using the historical data of China's electricity consumption in recent ten years, which were collected from China Statistical Yearbook [57], and the method for applying the estimates is explained in Ref. [58,59]. We obtain that the drift rate $\alpha=\bar{\mu} / \Delta t$, where $\bar{\mu}$ refers to the mean of $\mu_{i} ; \mu_{i}=\ln \left(E q_{t} / E q_{t-1}\right)$, where $E q_{t}$ denotes the quantity of electricity consumed at the end of one year; $\Delta t$ represents the length of time interval by using one year as the unit; and that volatility rate $\sigma=\mathrm{S} / \sqrt{\Delta t}$, where $\mathrm{S}=\sqrt{1 /(l-1) \cdot \sum_{i=1}^{l}\left(\mu_{i}-\bar{\mu}\right)^{2}}$, and $l+1$ is the amount of observations. Hence, the drift term can be calculated as $\alpha=0.07$, and the volatility can be calculated as $\sigma=0.04$.

Table 1. Input data of the parameters.

\begin{tabular}{lcc}
\hline \multicolumn{1}{c}{ Parameters } & Description & Value \\
\hline Market price of electricity & $E p_{t}^{d}$ & $0.65 \mathrm{CNY} / \mathrm{kWh}$ \\
\hline Unit capacity cost of solar PV system & $U I_{t}$ & $5000 \mathrm{CNY} / \mathrm{kW}$ \\
\hline Unit production and operation cost & $u m o c_{t}$ & $0.2 \mathrm{CNY} / \mathrm{kWh}$ \\
\hline The amount of electricity by unit solar PV system & $E q_{t}^{e}$ & $1500 \mathrm{kWh}$ \\
\hline $\begin{array}{l}\text { The proportion between upfront costs and initial capital } \\
\text { costs in PV power project }\end{array}$ & $\gamma$ & 0.039 \\
\hline $\begin{array}{l}\text { The land-use rent fee as a portion of the revenues through } \\
\text { electricity sales in BOT photovoltaic power project }\end{array}$ & $\varepsilon$ & 0.08 \\
\hline Lifetime of PV power project & $T_{f}$ & $25 \mathrm{years}$ \\
\hline The amount of coal consumption by unit coal-fired power & $Q_{e}$ & $0.286 \mathrm{~kg} / \mathrm{kWh}$ \\
\hline Market price of unit Coal & $\beta$ & $0.65 \mathrm{CNY} / \mathrm{kg}$ \\
\hline The amount of emissions by unit coal-fired power & $Q_{c}$ & $0.997 \mathrm{~kg} / \mathrm{kWh}$ \\
\hline Market price of unit carbon emission & $\omega$ & $0.15 \mathrm{CNY} / \mathrm{kg}$ \\
\hline Discount rate & $r$ & 0.1 \\
\hline
\end{tabular}

\subsection{Scenario Analysis of the Optimal Concession Period for PV Project Using BOT Mode}

\subsubsection{Optimal Concession Period under Initial Scenario}

To determine the optimal concession period for the BOT solar photovoltaic power project under policy incentives, we then apply the model formulated in Section 3 by using the data described above. According to Equation (37), the equilibrium concession period is mainly influenced by the relative benefit-costs of both the private sector and the government, where the benefit-cost of the private sector is associated with the lower limit of the concession period for the BOT project on the basis of Equation (13), and the benefit-cost of the government is associated with the upper limit of the concession period for the BOT project in the light of Equation (24). Then, we take the scenario that the electricity price subsidy is $0.37 \mathrm{CNY} / \mathrm{kWh}$, and the initial cost subsidy is $0.2 \mathrm{CNY} / \mathrm{W}$ as the initial state.

With the parameter values as given, the equilibrium value of the concession period is 23.61 years, and the effective interval of the concession period ranges from 18.7 years to 24.1 years. As the equilibrium value of the concession period is located in the effective interval of the concession period and for it to be smaller than the project lifetime, which is 25 years, the BOT solar PV power generation project can be implemented successfully under this initial scenario. Figure 3 presents the curve for the accumulative NPV of both the private sector and the government under the initial scenario. As shown in Figure 3, the break-even point of the private sector's option value for the BOT solar PV power implementation is in the fourth year, and its accumulative net present value is $1.43\left(10^{8} \mathrm{CNY}\right)$ (when 
the concession period is 23.6 years). Meanwhile for the government, the break-even point of the option value is about in the ninth year of the PV power generation project, and the accumulative net present value of the government at the end of the project lifetime reaches $0.12\left(10^{8} \mathrm{CNY}\right)$.

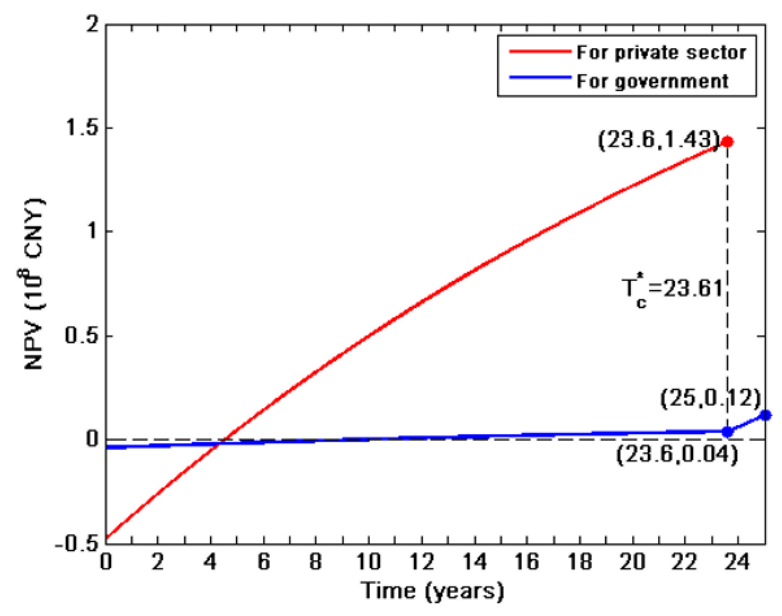

Figure 3. The accumulative net present values for the private sector and the government under initial scenario. Notes: NPV—accumulative net present value (unit: $10^{8} \mathrm{CNY}$ ).

\subsubsection{Sensitivity Analysis}

In light of Equations (13), (24), and (37), many factors, including unit generating capacity, subsidy level, market electricity price, investment cost, and the land-use rent fee for the BOT solar PV power project, could affect the determination of the concession period. It should be meaningful to investigate the impacts of these factors on the concession period determination by conducting sensitivity analysis. On the basis of this, some useful findings should be obtained to guide the BOT application to solar PV power project.

(1) Unit generating capacity

The dynamics of the equilibrium value of concession period and its effective interval under the changes of unit generating capacity is presented in Figure 4. The generating capacity of unit solar PV system mainly depends on the endowment of the solar energy resource. At present, the range of unit generating capacity of PV generation is about 1000 to $1800 \mathrm{kWh}$ in China. It can be seen from Figure 4 that the equilibrium value of the concession period is fixed at 23.6 years with the increase of the concession period. The effective interval is broadened at an average rate of $7.9 \%$, in which the lower limit of concession period decreases from 33.4 years at the lowest capacity level to 14.8 years at the highest capacity level with an average reduction rate of $7.0 \%$, and the upper limit of concession period increases from 22.9 years at the lowest capacity level to 24.5 years at the highest capacity level with an average growth rate of $0.9 \%$. If the generating capacity is raised to be higher than $1250 \mathrm{kWh}$, the BOT solar PV power project can be arranged with the optimal concession period, which is within the effective interval. However, if the generating capacity falls below this level, no feasible concession period for the PV power project would exist, as the upper limit of the concession period that the government can permit falls below the lower limit that the private sector can accept. At this time, extra policy incentives should be provided by the government for helping the PV power project win the BOT contract. 


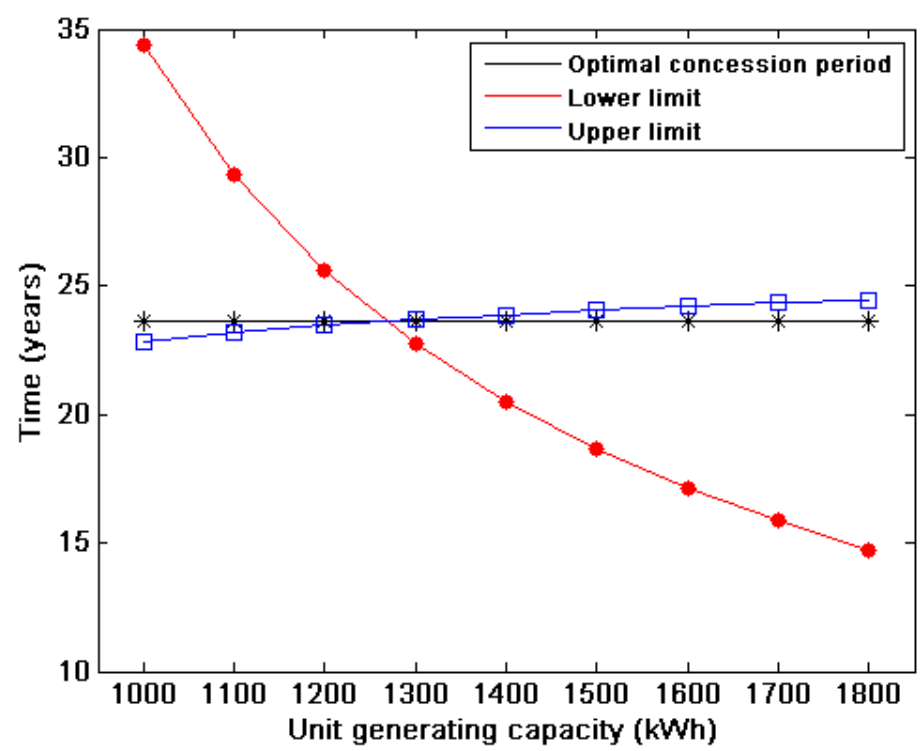

Figure 4. The influence of unit generating capacity.

Some policy implications are provided according the analysis above. Although solar energy resources are abundant in China, an extremely uneven distribution for the resources of solar energy exists. Hence, it is better for the government to make sub-regional adjustments to the incentive policies, i.e., FIT and initial cost subsidies, for successfully implementing the BOT solar PV power project with lower government support. Besides, as the unit generating capacity could be improved by increasing the power generation efficiency of photovoltaic systems, some measures should be taken, such as increasing research and development investment and improving energy management.

As the generating capacity aims to satisfy the electricity demand, we conducted the sensitivity analysis for the volatility of electricity demand. Figure 5 displays the dynamics of the equilibrium value of concession period and its effective interval under different volatility levels of electricity demand. As with the generating capacity, the equilibrium value of the concession period is fixed with the increase of electricity demand volatility. However, the effective interval is narrowed at an average rate $4.1 \%$, where the lower limit of the concession period is increased with an average growth rate of $3.8 \%$, and the higher limit of the concession period is decreased with an average reduction rate of $0.3 \%$. As long as the demand volatility rate is increased to 0.17 , the upper limit of the concession period that the government can permit would be higher than the lower limit of the concession period that the private sector can accept, which means the failure to win the BOT contract for PV project. To eliminate the negative effects from the volatility of high electricity demand, the government can perfect market planning and construction, improve the policy system, and enhance the communication and interaction with end-users to maintain the stability of consumers' electricity demand. 


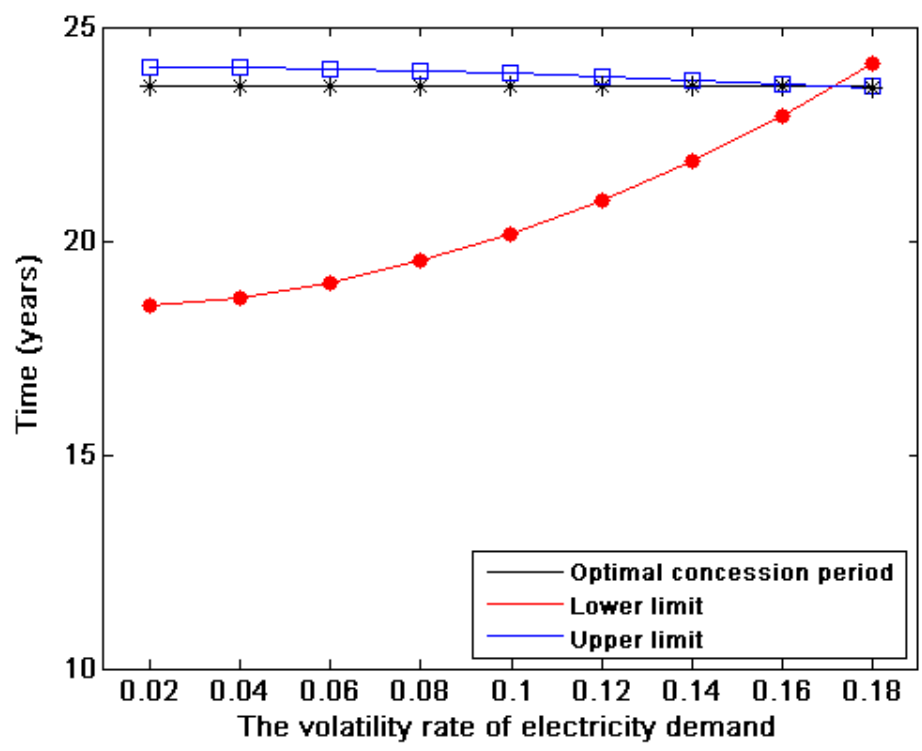

Figure 5. The influence of electricity demand volatility.

(2) Subsidy level

Figure 6 shows the dynamics of the equilibrium value of concession period and its effective interval under the change of initial cost subsidy. As presented in Figure 6, when the initial cost subsidy increases from $0.1 \mathrm{CNY} / \mathrm{W}$ to $0.9 \mathrm{CNY} / \mathrm{W}$, the equilibrium value of the concession period is decreased from 24.3 years to 18.9 years with an average reduction rate of $2.8 \%$, and the effective interval of the concession period is broadened slightly at an average rate $0.2 \%$, in which the lower limit of the concession period decreases from 19.2 years to 15.2 years with an average reduction rate of $2.6 \%$, and the upper limit of the concession period decreases from 24.7 years to 20 years with an average reduction rate of $2.4 \%$. As for China, the average initial cost subsidy for the PV power generation project is about $0.2 \mathrm{CNY} / \mathrm{W}$ at present, and it should be not enough to support the implementation of the BOT photovoltaic power project. As shown in Figure 6, when the price subsidy for the PV project decreases to $0.23 \mathrm{CNY} / \mathrm{kWh}$, the lower limit of the concession period would be higher than 25 years, which is the project lifetime of the solar PV system.

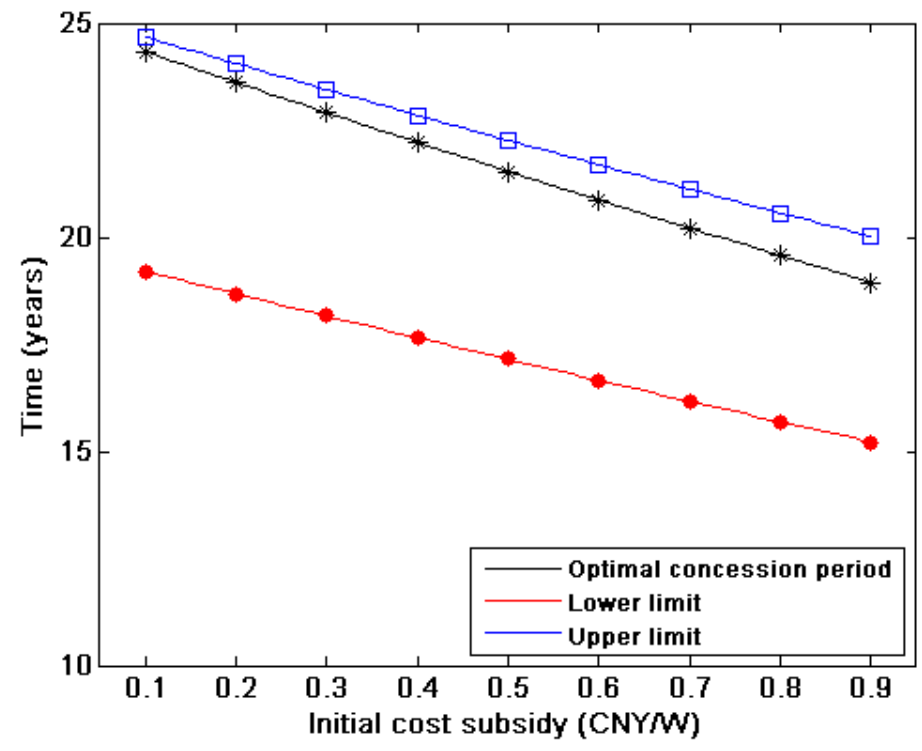

Figure 6. The influence of initial cost subsidy. 
Figure 7 shows the dynamics of the equilibrium value of the concession period and its effective interval under the change of electricity price subsidy, i.e., the FIT policy. As presented in Figure 7, the FIT mechanism has a significant effect on the changes of the concession period. The equilibrium value of the concession period decreases from 47.1 years to 12.3 years with an average reduction rate of $9.2 \%$. The lower limit of the concession period and the upper limit respectively decrease with an average reduction rate of $9.3 \%$ and $8.8 \%$, which leads to the effective interval of the concession period broadening slightly at an average rate of $0.5 \%$. The average electricity price subsidy in China is $0.37 \mathrm{CNY} / \mathrm{kWh}$ for PV power generation, and it is sufficient to trigger the BOT project investment since the equilibrium value of the concession period and its effective interval are both within the reasonable ranges at this subsidy level.

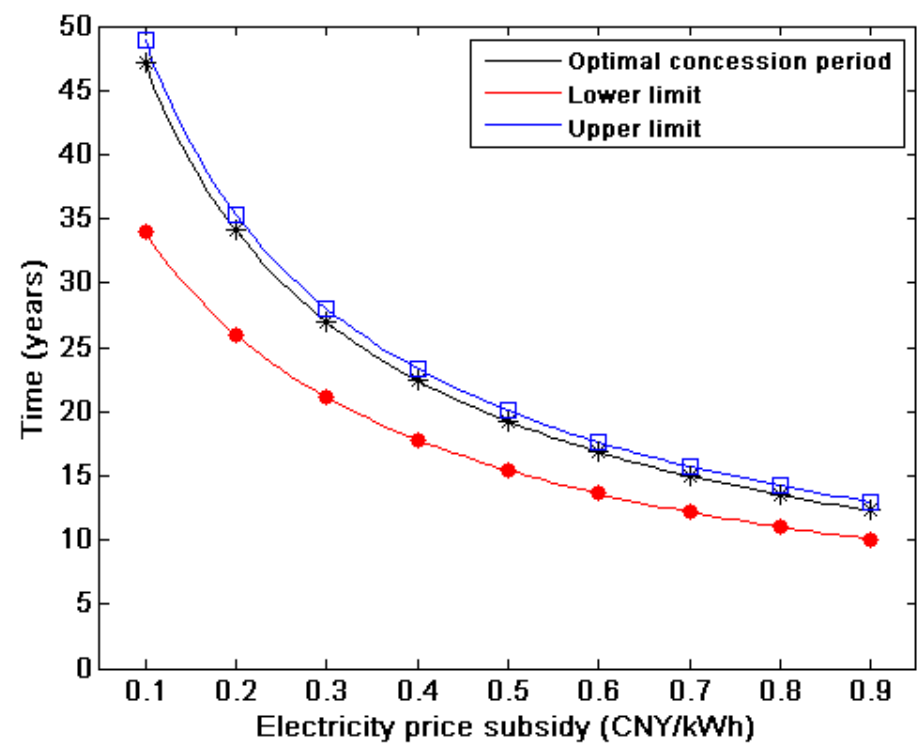

Figure 7. The influence of electricity price subsidy.

Based on the analysis described above, both the FIT mechanism and the initial cost subsidy can help obtain the optimal concession period, and the FIT mechanism has a more significant effect than the initial cost subsidy. Under this method, the effects of different subsidy levels could be estimated and then be used to guide the implementation of the BOT solar PV power project. To promote the investment in the BOT project, the government should properly adjust the levels of different subsidies and make appropriate arrangements for the BOT contract. Besides, both the subsidies' level could be changed if the PV technology and market environment are improved.

(3) Market price of electricity

The dynamics of the equilibrium value of concession period and its effective interval under the change of market price of electricity is presented in Figure 8. In China, the market electricity price is distinct in different regions, and the FIT for photovoltaic generation is determined according to the level of market electricity price. As can be seen from Figure 8, the equilibrium value of the concession period increases with a small average growth rate of $0.7 \%$ with the increase of the electricity price, and the effective interval is broadened significantly with an average rate of $10.5 \%$, where the lower limit of concession period decreases from 32.0 years to 9.9 years with an average reduction rate of $8.6 \%$, and the upper limit of concession period increases from 22.3 years to 25.7 years at an average rate of $1.9 \%$. When the electric price exceeds $0.52 \mathrm{CNY} / \mathrm{kWh}$, the BOT solar PV power project can be arranged with the optimal concession period. In contrast, once the market price of electricity falls below this level, the PV power project would fail to be arranged with a BOT contract since no feasible concession period exists at this moment, where the upper limit of concession period is below its lower limit. 


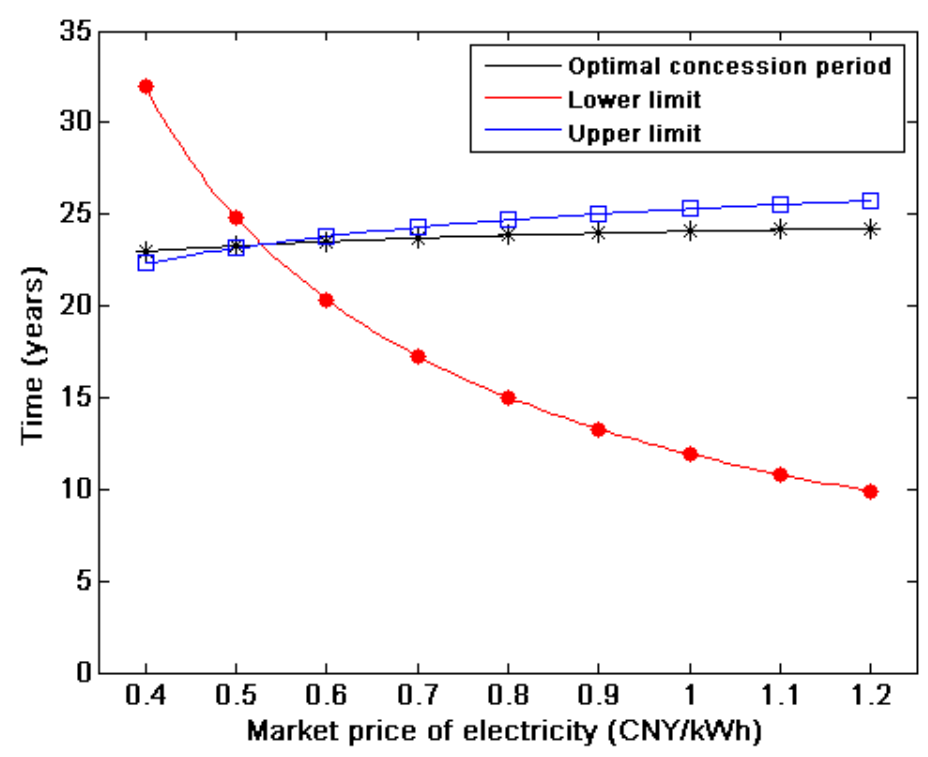

Figure 8. The influence of market electricity price.

Hereon, the effect of the market electricity price on determining the concession period is estimated. Since the market electricity price cannot be raised freely, some measures should be taken if the electricity price is too low to support the implementation of a BOT solar PV power project. According to the analysis above, increasing unit generating capacity and subsidy levels, which includes initial cost subsidy and price subsidy, can both help solve the problem caused by low levels of electricity price. By comparison, the effect of unit generating capacity is more significant than the effect of the subsidies in broadening the effective interval for the concession period. Hence, the government should strongly strengthen the research and development investment for promoting the development of the BOT solar PV power project.

(4) Investment cost

The dynamics of the equilibrium value of the concession period and its effective interval vary under the change of unit investment cost, as shown in Figure 9. Because of the immaturity of the PV generation technology, the investment of the PV project under BOT mode can be affected by its high investment cost. It can be seen from Figure 9 that when the unit investment cost ranges from $1000 \mathrm{CNY}$ to $9000 \mathrm{CNY}$, the equilibrium value of the concession period is increased from 18.3 years to 24.3 years at an average rate of $4.04 \%$, and the effective interval of concession period is narrowed significantly at an average reduction rate of $248.7 \%$, in which the lower limit of concession period is increased from 2.5 years to 52.5 years with an average growth rate of $247.7 \%$, and its upper limit is decreased $25.0 \%$ to 23.1 years with an average reduction rate of $1.0 \%$. As long as the unit investment cost is decreased to be lower than $6000 \mathrm{CNY}$, the BOT solar PV power project can be arranged with the optimal concession period. Apparently, the high investment cost cannot help obtain the optimal concession period but acts as one of the most critical factors impeding the investment of the BOT solar PV project. To solve this problem, the most effective method is to stimulate technology development. The government should increase research and development investment, cultivate high-qualified research and development talents, as well as strengthen the cooperation with international countries with mature technology. Furthermore, a smart financing mode for the BOT solar PV power project can help alleviate this problem. 


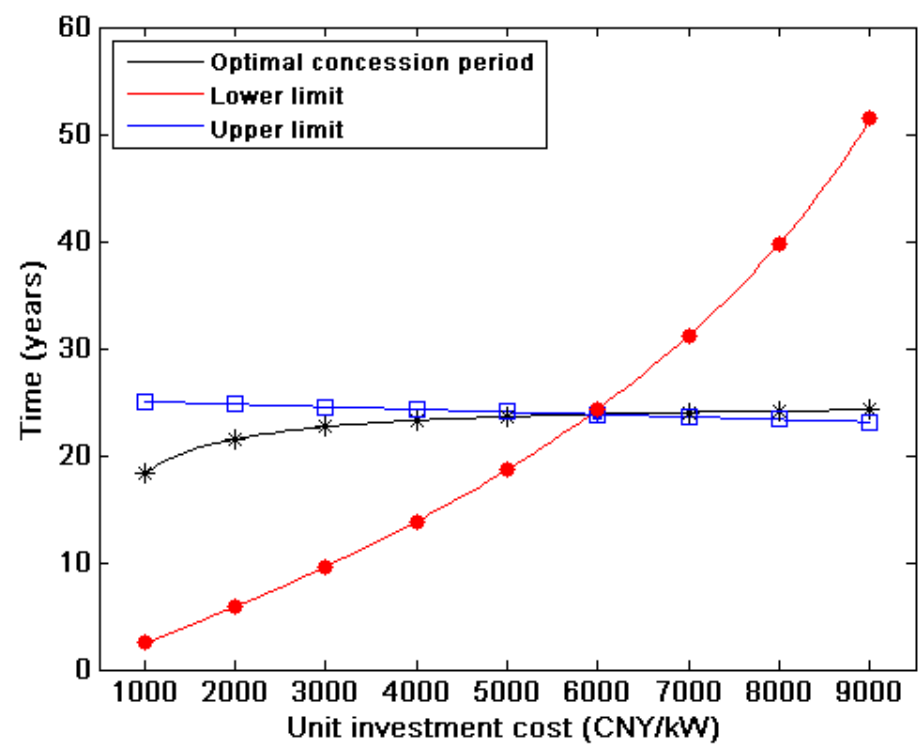

Figure 9. The influence of investment cost.

(5) Land-use rent fee

Figure 10 presents the dynamics of the equilibrium value of the concession period and its effective interval under different levels of land-use rent fees. In China, the land-use fee of the BOT photovoltaic power project is determined by the project's benefits through selling electricity, and it is only charged by the government within the concession period when the private sector operates the PV power project. As shown in Figure 10, the equilibrium value of concession period increases from 22.9 years to 24.4 years with an average rate of $0.8 \%$ when the level of the land-use rent fee ranges from 0.04 to 0.12 , and the effective interval of the concession period is narrowed at an average rate of $0.5 \%$ as the lower limit of concession period increases from 17.7 years to 19.8 years with an average growth rate of $1.5 \%$, and the upper limit increases from 23.2 years to 25 years with an average growth rate of $1.0 \%$. At present, the average land-use rent fee is about 0.08 for the BOT solar PV power generation project in China, and it is reasonable for the BOT project implementation. As can be seen from Figure 10, the BOT solar PV power project can be arranged with the optimal concession period at this level of land-use rent fee. It should be noted that the land-use rent fee could be gradually improved with the increase of $\mathrm{PV}$ power generation efficiency year by year.

To conclude, the current investment environment in China could successfully implement the BOT solar PV power project under policy incentives. In this study, we considered the initial cost subsidy and feed-in tariffs (FIT) mechanism for BOT solar PV power project implementation. Besides, since the high volatility of electricity demand, investment cost, and land-use rent fee could lead to solar PV power project to failure in obtaining a feasible concession period, the increase of unit generating capacity and policy incentives could help the PV project to be arranged with an optimal concession period. Thus, promoting technology development of PV power generation, maintaining the market stability, and increasing policy incentives can help the BOT power project win the BOT contract. Additionally, the feed-in tariffs mechanism has a more significant effect than the initial cost subsidy for the PV power project under BOT mode. 


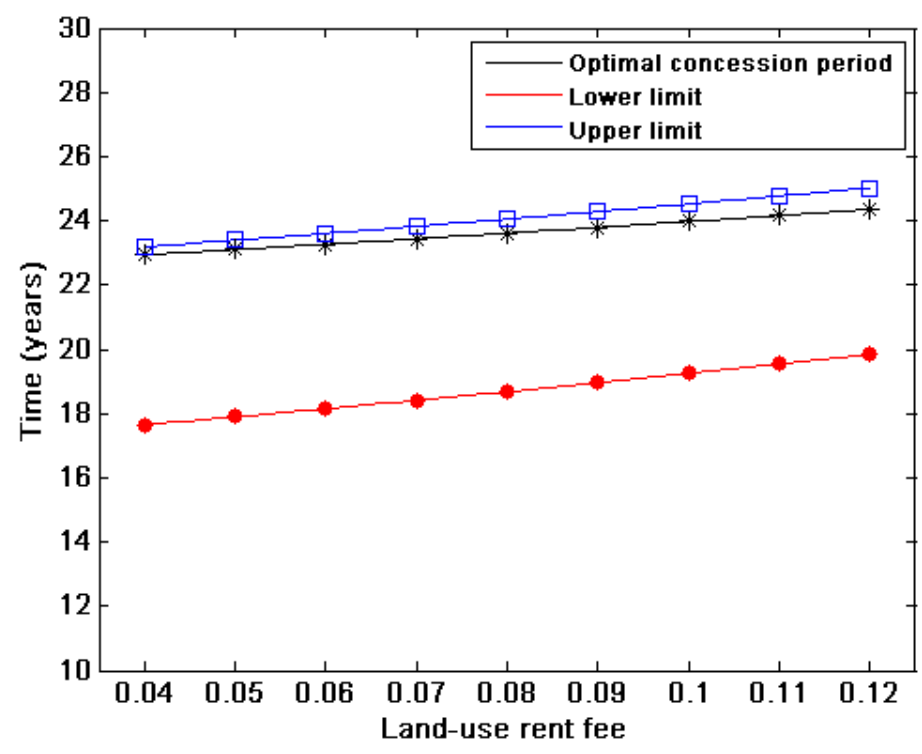

Figure 10. The influence of land-use rent fee.

\section{Conclusions and Policy Implications}

It is acknowledged that the investment of solar PV power generation is still constrained by high capital costs, and the build-operate-transfer mode has been identified as an effective way for attracting social capital to invest in the PV power generation project, which can both alleviate the financial pressure of the government and stimulate private participation in power investment. Since the concession period is the key decision variable for arranging a BOT contract, this paper presents a cooperative game model integrated with real option, which considers the value of the option to defer, to determine the optimal concession period for a BOT solar PV power project under policy incentives. In the proposed model, an effective interval of concession period for the BOT project is identified by using real option theory, and the equilibrium concession period is obtained by applying classical optimization theory. We then investigated the effects of relevant influential factors, which include unit generating capacity, initial cost subsidy, electricity price subsidy, market price of electricity, investment cost, and the land-use fee, for the determination of concession period by conducting sensitivity analysis.

To verify the feasibility of this proposed model, we empirically applied it to determine the concession period of the BOT photovoltaic power project in China. The results demonstrate that the current investment environment in China could successfully implement the BOT solar PV power project under policy incentives, which include initial cost subsidy and the feed-in tariffs (FIT) mechanism. While the increase of the volatility in electricity demand, investment cost, and land-use rent fee could lead to the failure of BOT solar PV power project implementation, the increase of unit generating capacity and the subsidy level (including both FIT and the initial cost subsidy) can help the BOT solar PV power project be arranged with the optimal concession period. The high market price of electricity could broaden the effective interval of the concession period, although it increases the equilibrium value of the concession period. According to the investigation, a synthetic adjustment for successfully implementing a PV power project under BOT mode could be made. Through the empirical analysis on the PV industry in China, the model can also be applied to other renewable energy generation that adopts the BOT mode and to other countries in the world.

Future extensions of this research could occur along several directions. Firstly, although our proposed model considers the relevant influential factors as much as possible, there are other factors that should be taken into account, such as the financing mode for the investors; relevant insurance including property insurance, damage insurance, and performance compensation clauses for the project generating capacity, etc.; research and development investment, which can also impact the concession period determination for the BOT project. Secondly, the changes in PV system generating 
capacity due to technological progress and also the aging phenomenon should be considered. Thirdly, the influences of additional policy incentives on concession period determination could be explored, e.g., tax incentives, since we only considered the FIT mechanism and initial cost subsidy for the investment of the BOT solar PV power project, which may be insufficient.

Author Contributions: Data curation, Y.Z.; methodology, Y.Z.; formal analysis, Y.Z.; writing—original draft, Y.Z.; writing-review and editing, W.C.

Funding: The authors sincerely acknowledge the financial support from the Major Research Plan of National Social Science Fund of China (No. 14ZDB135), the General Program of National Natural Science Foundation of China (No. 71373173), and the Major Research Plan of Social Science Found of Tianjin Municipal Education Commission (No. 2018JWZD51).

Conflicts of Interest: The authors declare no conflict of interest.

\section{Nomenclature}

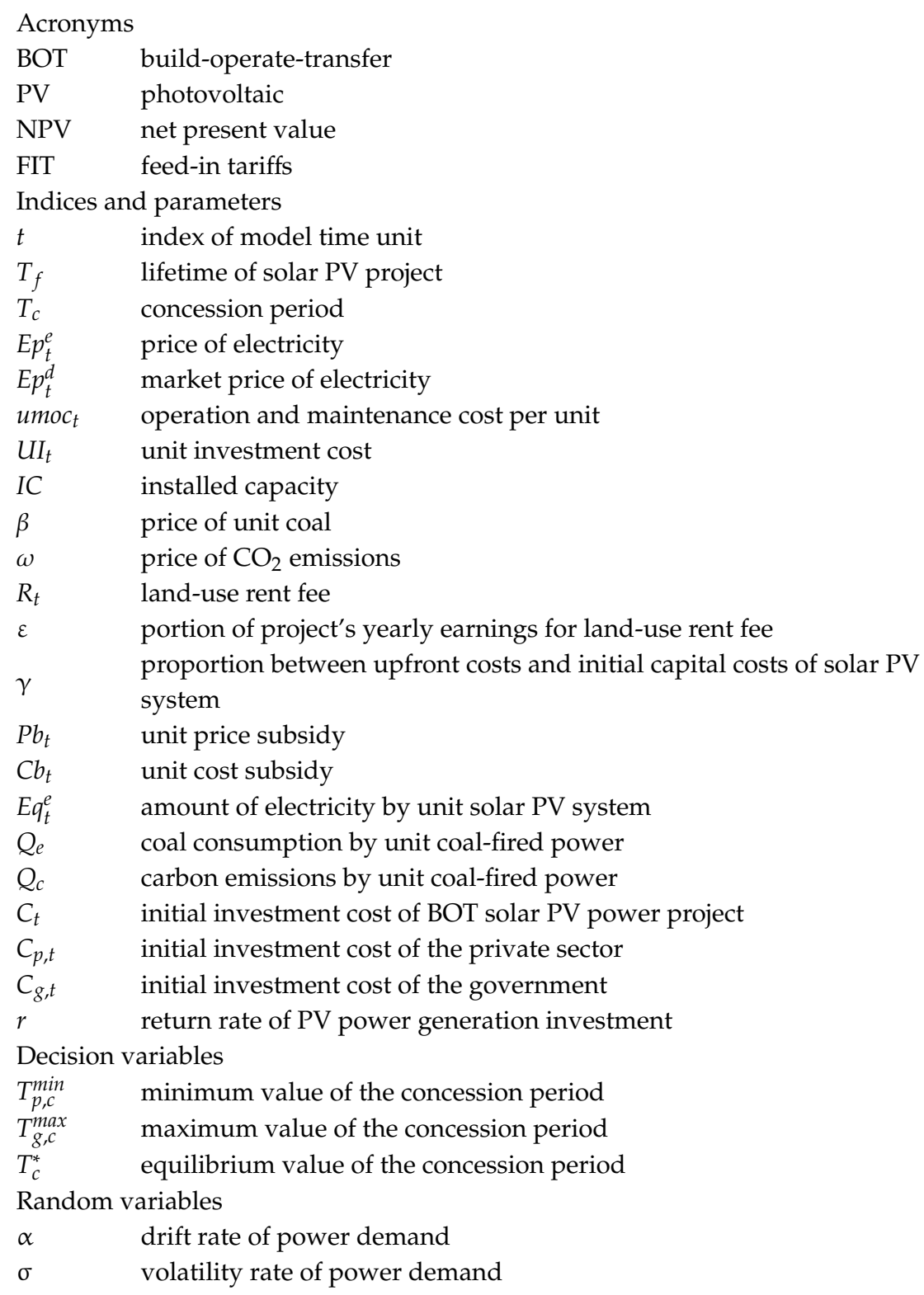




\section{References}

1. Guo, X.; Guo, X. China's photovoltaic power development under policy incentives: A system dynamics analysis. Energy 2015, 93, 589-598. [CrossRef]

2. Aquila, G.; Pamplona, E.D.O.; Queiroz, A.R.D.; Junior, P.R.; Fonseca, M.N. An overview of incentive policies for the expansion of renewable energy generation in electricity power systems and the Brazilian experience. Renew. Sustain. Energy Rev. 2017, 70, 1090-1098. [CrossRef]

3. He, Y.; Pang, Y.; Li, X.; Zhang, M. Dynamic subsidy model of photovoltaic distributed generation in China. Renew. Energy 2018, 118, 555-564. [CrossRef]

4. Wang, Y.; Zhou, S.; Hou, H. Cost and $\mathrm{CO}_{2}$ reductions of solar photovoltaic power generation in China: Perspectives for 2020. Renew. Sustain. Energy Rev. 2014, 30, 370-380. [CrossRef]

5. Liu, D.; Liu, M.; Xu, E.; Pang, B.; Guo, X.; Xiao, B.; Niu, D. Comprehensive effectiveness assessment of renewable energy generation policy: A partial equilibrium analysis in China. Energy Policy 2018, 115, 330-341. [CrossRef]

6. Zhang, S. Innovative business models and financing mechanisms for distributed solar PV (DSPV) deployment in China. Energy Policy 2016, 95, 458-467. [CrossRef]

7. Zeng, M.; Liu, X.M.; Li, Y.L.; Peng, L.L. Review of renewable energy investment and financing in China: Status, mode, issues and countermeasures. Renew. Sustain. Energy Rev. 2014, 31, 23-37.

8. Tan, Z.; Tan, Q.; Rong, M. Analysis on the financing status of PV industry in China and the ways of improvement. Renew. Sustain. Energy Rev. 2018, 93, 409-420. [CrossRef]

9. Zhao, Z.Y.; Zuo, J.; Zillante, G.; Wang, X.W. Critical success factors for BOT electric power projects in China: Thermal power versus wind power. Renew. Energy 2010, 35, 1283-1291. [CrossRef]

10. Zou, P.X.W.; Wang, S.; Fang, D. A life-cycle risk management framework for PPP infrastructure projects. J. Financ. Manag. Prop. Constr. 2008, 13, 123-142. [CrossRef]

11. Chen, C.; Doloi, H. BOT application in China: Driving and impeding factors. Int. J. Proj. Manag. 2008, 26, 388-398. [CrossRef]

12. Marco, A.D.; Mangano, G. The influence of risk on the equity share of build-operate-transfer projects. Built Environ. Proj. Asset Manag. 2017, 7, 45-58. [CrossRef]

13. Liu, P.; Chu, P. Renewables finance and investment: How to improve industry with private capital in China. J. Mod. Power Syst. Clean Energy. 2018. [CrossRef]

14. Kousksou, T.; Allouhi, A.; Belattar, M.; Jamil, A.; Rhafiki, T.E.; Arid, A.; Zeraouli, Y. Renewable energy potential and national policy directions for sustainable development in Morocco. Renew. Sustain. Energy Rev. 2015, 47, 46-57. [CrossRef]

15. Uner, M.M.; Çavuşgi, E.; Çavuşgi, S.T. Build-operate-transfer projects as a hybrid mode of market entry: The case of Yavuz Sultan Selim Bridge in Istanbul. Int. Bus. Rev. 2018, 27, 797-802. [CrossRef]

16. Zhao, Z.Y.; Zuo, J.; Zillante, G. Factors influencing the success of BOT power plant projects in China: A review. Renew. Sustain. Energy Rev. 2013, 22, 446-453. [CrossRef]

17. Lv, J.; Ye, G.; Liu, W.; Shen, L.; Wang, H. Alternative Model for Determining the Optimal Concession Period in Management BOT Transportation Project. J. Manag. Eng. 2015, 31, 04014066. [CrossRef]

18. Doan, P.; Menyah, K. Impact of irreversibility and uncertainty on the timing of infrastructure projects. J. Constr. Eng. Manag. 2013, 139, 331-338. [CrossRef]

19. Carbonara, N.; Costantino, N.; Pellegrino, R. Concession period for PPPs: A win-win model for a fair risk sharing. Int. J. Proj. Manag. 2014, 32, 1223-1232. [CrossRef]

20. Zhang, Z.; Bao, H.; Wang, H.; Skitmore, M. A model for determining the optimal project life span and concession period of BOT projects. Int. J. Proj. Manag. 2016, 34, 523-532. [CrossRef]

21. $\mathrm{Xu}, \mathrm{J} . \mathrm{W}$; Moon, S. A stochastic revenue and cost model for determining a BOT concession period under multiple project constraints. J. Manag. Eng. 2013, 30, 04014011. [CrossRef]

22. Huang, Y.L.; Pi,C.C. Real-option valuation of build-operate-transfer infrastructure projects under performance bonding. J. Constr. Eng. Manag. 2013, 140, 04013068. [CrossRef]

23. Zhang, X.; Abourizk, S.M. Determining a reasonable concession period for private sector provision of public works and service. Can. J. Civ. Eng. 2006, 33, 622-631. [CrossRef]

24. Liu, S.; Jin, H.; Xie, B.; Liu, C.; Mills, A. Concession period determination for PPP retirement village. Int. J. Strateg. Prop. Manag. 2018, 22, 424-435. [CrossRef] 
25. Ma, G.; Du, Q.; Wang, K. A concession period and Price Determination Model for PPP projects: Based on Real Options and Risk Allocation. Sustainability 2018, 10, 706.

26. Hanaoka, S.; Palapus, H.P. Reasonable concession period for build-operate-transfer road projects in the Philippines. Int. J. Proj. Manag. 2012, 30, 938-949. [CrossRef]

27. Song, J.; Jin, L.; Zhao, Y.; Hu, W. Using bargaining-game model to negotiate compensation for the early termination of BOT highway projects. Transp. Res. Part A Policy Pract. 2017, 105, 197-209. [CrossRef]

28. Peng, W.; Cui, Q.; Chen, J. Option Game Model for Optimizing Concession Length and Public Subsidies of Public-Private Partnerships. Transp. Res. Rec. J. Transp. Res. Board 2014, 2450, 109-117. [CrossRef]

29. Bao, H.; Peng, Y.; Ablanedo-Rosas, J.H.; Gao, H. An alternative incomplete information bargaining model for identifying the reasonable concession period of a BOT project. Int. J. Proj. Manag. 2015, 33, 1151-1159. [CrossRef]

30. Joskow, P.L.; Rose, N.L. The effects of economic regulation. In Handbook of Industrial Organization II; Schmalensee, R., Willig, R., Eds.; Elsevier Science: Amsterdam, The Netherlands, 1989.

31. Auriol, E.; Picard, P. A Theory of BOT Concession Contracts CORE Discussion Paper; Center for Research in Economic Analysis, University of Luxembourg: Luxembourg, 2011; p. 19.

32. Wang, F.; Xiong, M.; Niu, B.; Zhuo, X. Impact of government subsidy on BOT contract design: Price, demand, and concession period. Transp. Res. Part B Methodol. 2018, 110, 137-159. [CrossRef]

33. Aladă̆, H.; Işik, Z. Role of financial risks in BOT mega-transportation projects in developing countries. J. Manag. Eng. 2017, 33, 04017007. [CrossRef]

34. Bakatjan, S.; Arikan, M.; Tiong, R.L.K. Optimal capital structure model for BOT power projects in Turkey. J. Constr. Eng. Manag. 2003, 129, 89-97. [CrossRef]

35. Deng, Q.; Jiang, X.; Cui, Q.; Zhang, L. Strategic design of cost savings guarantee in energy performance contracting under uncertainty. Appl. Energy 2015, 139, 68-80. [CrossRef]

36. Xu, Y.; Chan, A.; Xia, B.; Qian, Q.; Liu, Y.; Peng, Y. Critical risk factors affecting the implementation of PPP waste-to-energy projects in China. Appl. Energy 2015, 158, 403-411. [CrossRef]

37. Deng, Q.; Zhang, L.; Cui, Q.; Jiang, X. A simulation-based decision model for designing contract period in building energy performance contracting. Build. Environ. 2014, 71, 71-80. [CrossRef]

38. Song, J.; Song, D.; Zhang, D. Modeling the concession period and subsidy for BOT waste-to-energy incineration projects. J. Constr. Eng. Manag. 2015, 141, 04015033. [CrossRef]

39. Gately, D. Sharing the gains from regional cooperation: A game theoretic application to planning investment in electric power. Int. Econ. Rev. 1974, 15, 195-208. [CrossRef]

40. Rau, P.; Spinler, S. Alliance formation in a cooperative container shipping game: Performance of a real options investment approach. Transp. Res. Part E Logist. Transp. Rev. 2017, 101, 155-175. [CrossRef]

41. Kumbaroğlu, G.; Madlener, R.; Demirel, M. A real options evaluation model for the diffusion prospects of new renewable power generation technologies. Energy Econ. 2008, 30, 1882-1908. [CrossRef]

42. Alvarez, L.H.R. Optimal exit and valuation under demand uncertainty: A real options approach. Eur. J. Oper. Res. 1999, 114, 320-329. [CrossRef]

43. Dulluri, S.; Raghavan, N.R.S. Collaboration in tool development and capacity investments in high technology manufacturing networks. Eur. J. Oper. Res. 2008, 187, 962-977. [CrossRef]

44. Adkins, R.; Paxson, D. The effects of an uncertain abandonment value on the investment decision. Eur. J. Financ. 2017, 23, 1083-1106. [CrossRef]

45. Dixit, A.K.; Pindyck, R.S. Investment under Uncertainty; Princeton University Press: Princeton, NJ, USA, 1994.

46. Azevedo, A.; Paxson, D. Developing real option game models. Eur. J. Oper. Res. 2014, 237, 909-920. [CrossRef]

47. Sampaio, P.G.V.; González, M.O.A. Photovoltaic solar energy: Conceptual framework. Renew. Sustain. Energy Rev. 2017, 74, 590-601. [CrossRef]

48. Zhao, H.; Guo, S.; Fu, L. Review on the costs and benefits of the renewable energy power subsidy in China. Renew. Sustain. Energy Rev. 2014, 37, 538-549. [CrossRef]

49. Kabir, E.; Kumar, P.; Kumar, S.; Adelodun, A.A.; Kim, K.H. Solar energy: Potential and future prospects. Renew. Sustain. Energy Rev. 2018, 82, 894-900. [CrossRef]

50. Chen, B.; Liou, F.M. Optimal capital structure of power plant projects with various bargaining powers in project negotiations. J. Energy Eng. 2017, 143, 04016051. [CrossRef]

51. Friedman, J.W. Game Theory with Applications to Economics; Oxford University Press: Oxford, UK, 1986. 
52. China Photovoltaic Industry Association. Available online: http://www.chinapv.org.cn (accessed on 1 February 2019).

53. National Energy Administration. Photovoltaic Power Generation Statistics in 2018. Available online: http://www.nea.gov.cn/2019-03/19/c_137907428.htm (accessed on 1 March 2019).

54. Lin, B.Q.; Wesseh, P.K., Jr. Valuing Chinese feed-in tariffs program for solar power generation: A real options analysis. Renew. Sustain. Energy Rev. 2013, 14, 113-147. [CrossRef]

55. Zhang, M.M.; Zhou, D.Q.; Zhou, P.; Liu, G.Q. Optimal feed-in tariff for solar photovoltaic power generation in China: A real options analysis. Energy Policy 2016, 97, 181-192. [CrossRef]

56. Zhao, C.; Zhang, W.; Wang, Y.; Liu, Q.; Guo, J.; Xiong, M.; Yuan, J. The economics of coal power generation in China. Energy Policy 2017, 105, 1-9. [CrossRef]

57. China Statistical Yearbook. Available online: http://www.stats.gov.cn/tjsj/ (accessed on 1 March 2018).

58. Insley, M. A real options approach to the valuation of a forest investment. J. Environ. Econ. Manag. 2002, 44, 471-492. [CrossRef]

59. Qdr, Q. Benefits of Demand Response in Electricity Markets and Recommendations for Achieving Them; US Department of Energy: Washington, DC, USA, 2006.

(C) 2019 by the authors. Licensee MDPI, Basel, Switzerland. This article is an open access article distributed under the terms and conditions of the Creative Commons Attribution (CC BY) license (http://creativecommons.org/licenses/by/4.0/). 